\title{
De cirkel is rond
}

\section{Artsen die in 2017 de Kaderopleiding Palliatieve Zorg volgden, schreven allen een kort verhaal over een palliatieve zorgervaring. Pallium publiceert een selectie daarvan. In dit nummer een bijdrage van Anouk Bovenkerk.}

Jaren '80. Een meisje van tien met twee vlechtjes in haar haar.

Iedere maandagmiddag na schooltijd worden mijn jongere broertje en ik door mijn opa en oma afgezet bij de school waar mijn moeder werkt. Teamvergadering tot 18 uur. Door de grote ramen zwaaien we van buiten naar mijn moeder en haar vergaderende collega's. Iedereen zwaait uitbundig terug. Eenmaal binnen in het kleine keukentje moeten we fluisteren om de vergaderende volwassenen niet te storen. Best moeilijk en ook een beetje spannend vinden we het. In het keukentje staat conciërge Willem ons op te wachten met limonade. Kleine pretoogjes, zachte blik. Een man van weinig woorden. Wel altijd een knipoog, een zacht rukje aan mijn vlecht, en die heerlijke felgekleurde limonade.

Iedere week hetzelfde veilige ritueel. Buitenschoolse opvang op z'n best.

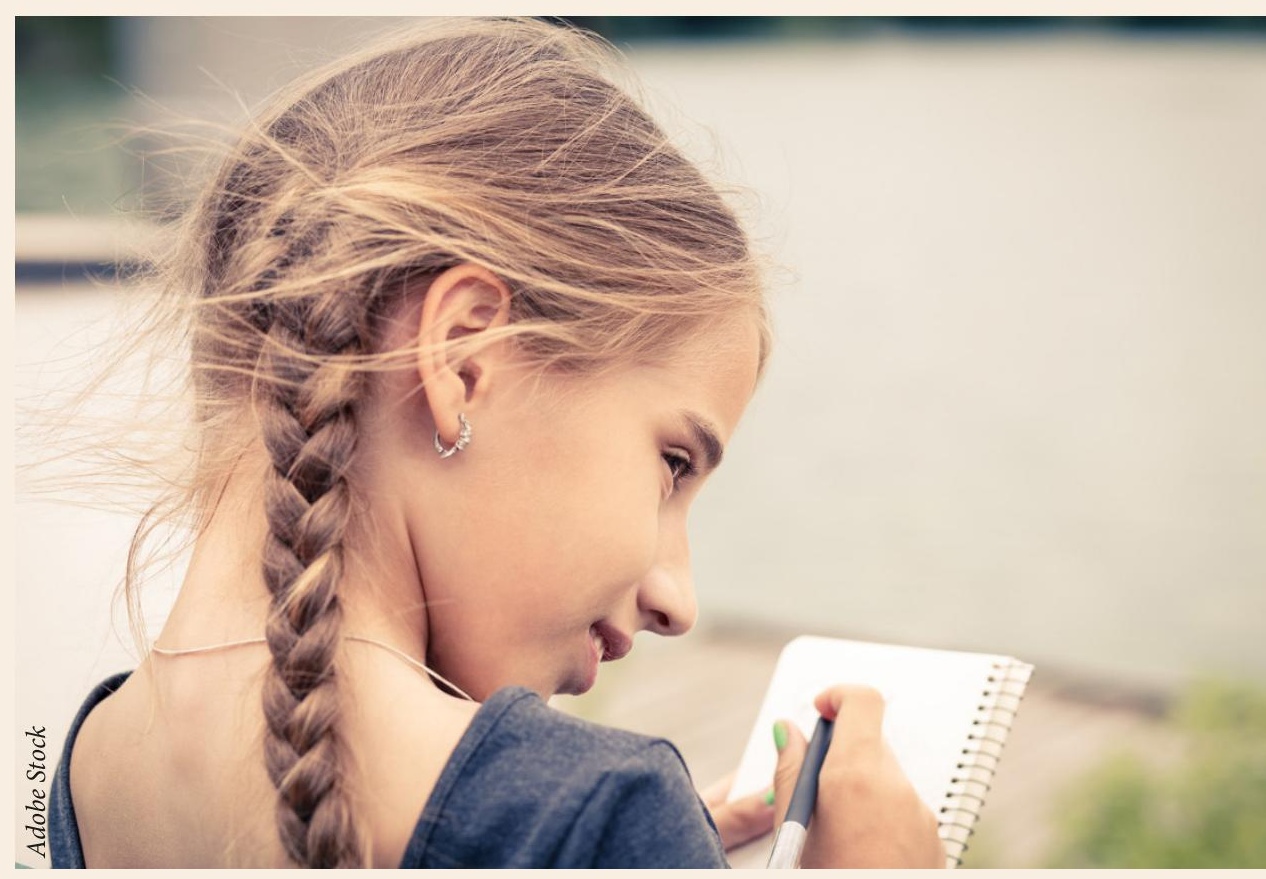

\section{'De cirkel is rond. Hij zorgde ooit voor mij, ik zorg nu voor hem'}

\section{Vertrouwen}

Ruim 30 jaar later. Hij is ernstig ziek, heeft uitgezaaid longkanker. Maar nog steeds die pretoogjes en die zachte blik. En ik ben zijn huisarts.

Toen hij bij me kwam met een hoestje dat maar niet over ging en hij deze vreselijke ziekte bleek te hebben, dacht ik even dat hij een andere huisarts zou willen. Misschien zou hij me nog als het kleine meisje met de vlechtjes zien. Niets bleek minder waar. Ik kreeg het volste vertrouwen van Willem en zijn vrouw om ze te begeleiden.

De cirkel is rond. Hij zorgde ooit voor mij, ik zorg nu voor hem.

\section{Zakdoek}

En nu dit onvermijdelijke moment. Natuurlijk wisten we dat het ging komen. Willem is stervende. Zijn vrouw heeft ons even alleen gelaten. Dan kunnen jullie nog wat tegen elkaar zeggen, zei ze.

Ik zit naast zijn bed. Een man van weinig woorden. De pretoogjes staan droeviger, maar nog steeds die lieve blik. Als hij een schone zakdoek uit het laatje van zijn nachtkastje pakt en deze aan mij geeft, merk ik pas dat ik zit te huilen. Als ik nog vlechtjes had, zou hij er een rukje aan hebben gegeven. Die knipoog krijg ik nog wel. •
Anouk Bovenkerk is kaderarts palliatieve zorg. 